Dr. Jorge A. R. Navarro

Departamento de Química Inorgánica,

Facultad de Ciencias, Universidad de Granada

Av. Fuentenueva S/N, 18071 Granada, SPAIN

Tel. +34-958240442

Fax: +34-958248526

E-mail: jarn@ugr.es

\title{
Mineralomimetic Sodalite and Muscovite Type Coordination Frameworks. Dynamic Crystal to Crystal Interconversion Processes Sensitive to Ion Pair Recognition
}

\author{
Elisa Barea, ${ }^{a}$ Jorge A. R. Navarro, ${ }^{a, *}$ Juan M. Salas, ${ }^{a, *}$ Norberto Masciocchi, ${ }^{b, *}$ Simona Galli ${ }^{b}$ and Angelo Sironi ${ }^{c}$ \\ a) Departamento de Química Inorgánica, Universidad de Granada, Av. Fuentenueva S/N, E-18071 Granada, Spain; b) Dipartimento di \\ Scienze Chimiche, Fisiche e Matematiche, Università degli Studi dell'Insubria, via Valleggio 11, I-22100 Como, Italy; c) Dipartimento di \\ Chimica Strutturale e Stereochimica Inorganica, Università di Milano, and ISTM-CNR, via G. Venezian 21, I-20133 Milano, Italy.
}

\section{Experimental Section}

Materials. 2-Hydroxypyrimidine $\cdot \mathrm{HCl}$ was purchased from Aldrich. $\left[\mathrm{Cu}(2-\mathrm{pymo})_{2}\right] \cdot \mathrm{nH}_{2} \mathrm{O}\left(\mathbf{1}_{\mathbf{R}}\right)$ was prepared as previously reported. ${ }^{1}$

Note: Apart from the evacuated $\mathbf{1}_{C}$, all species host, in their MOF channels, a number of water molecules.

\footnotetext{
${ }^{1}$ Tabares, L. C.; Navarro, J. A. R.; Salas, J. M. J. Am. Chem. Soc. 2001, 123, 383.
} 
Preparation of $\left[\mathrm{Cu}(2-\mathrm{pymo})_{2}\right] \cdot\left(\mathrm{M}\left(\mathrm{NO}_{3}\right)_{\mathrm{m}}\right)_{1 / 3}\left(\mathrm{M}\left(\mathrm{NO}_{3}\right)_{\mathrm{m}} @ 1_{\mathrm{C}}\right),\left(\mathrm{M}=\mathrm{NH}_{4}{ }^{+}, \mathrm{Li}^{+}, \mathrm{Na}^{+}, \mathrm{K}^{+}, \mathrm{Rb}^{+}, \mathrm{Tl}^{+}\right.$, $\left.\mathbf{L a}^{3+}\right)$. Microcrystalline purple $\mathbf{M}\left(\mathbf{N O}_{3}\right)_{\mathbf{m}} @ \mathbf{1}_{\mathbf{C}}$ clathrates were obtained by suspending $\mathbf{1}_{\mathbf{R}}$ in $0.05 \mathrm{M}$ water:methanol (1:4) solutions of the corresponding nitrate salts at room temperature. When $\mathrm{M}=\mathrm{NH}_{4}{ }^{+}$, $\mathrm{Li}^{+}$the thermodynamic equilibrium for the solid-liquid sorption process is reached after 1 week, giving the corresponding $\left[\mathrm{Cu}(2-\text { pymo })_{2}\right] \cdot\left(\mathrm{MNO}_{3}\right)_{1 / 3}$ clathrates. However, it should be noted that for $\mathrm{M}=\mathrm{Na}^{+}$, $\mathrm{K}^{+}, \mathrm{Rb}^{+}, \mathrm{Tl}^{+}, \mathrm{La}^{3+}$ the cubic $\mathbf{M}\left(\mathrm{NO}_{3}\right)_{\mathbf{m}} @ \mathbf{1}_{\mathbf{C}}$ systems are intermediate phases prior to the formation of the thermodynamically stable orthorhombic $\mathbf{M}\left(\mathbf{N O}_{3}\right)_{\mathbf{m}} @ \mathbf{1}_{\mathbf{O}}$ ones (see below). The intermediate $\mathbf{M}\left(\mathrm{NO}_{3}\right)_{\mathbf{m}} @ \mathbf{1}_{\mathbf{C}}$ phases can be isolated after optimal sorption periods ranging from 6 hours for $\mathrm{M}=\mathrm{La}^{3+}$, 48 hours for $\mathrm{M}=\mathrm{Na}^{+}$to 72 hours for $\mathrm{M}=\mathrm{K}^{+}, \mathrm{Rb}^{+}, \mathrm{Tl}^{+}$. These systems have been characterised by $\mathrm{EA}$, IR and XRPD methods confirming their $\mathbf{M}\left(\mathbf{N O}_{3}\right)_{\mathrm{m}} @ \mathbf{1}_{\mathbf{C}}$ nature.

Crystals of $\mathbf{N H}_{\mathbf{4}} \mathbf{N O}_{3} @ \mathbf{1}_{\mathbf{C}}$ and $\mathbf{L i N O}_{\mathbf{3}} @ \mathbf{1}_{\mathbf{C}}$ were grown from an ammonia:water:methanol (2:11:7) solution $(25 \mathrm{~mL})$ containing $\mathrm{Cu}\left(\mathrm{NO}_{3}\right)_{2} \cdot 3 \mathrm{H}_{2} \mathrm{O}(2 \mathrm{mmol})$, 2-hydroxypyrimidine $\cdot \mathrm{HCl}(4 \mathrm{mmol})$ and $\mathrm{MNO}_{3}(1 \mathrm{mmol})$. Dark purple crystals of $\mathbf{N H}_{\mathbf{4}} \mathbf{N O}_{3} @ \mathbf{1}_{\mathbf{C}}$ and $\mathbf{L i N O} \mathbf{H}_{3} @ \mathbf{1}_{\mathbf{C}}$ were isolated within one day.

Elemental analyses:

$\mathbf{N H}_{4} \mathbf{N O}_{3} @ 1_{\mathbf{C}}$. Yield $85 \% . \mathrm{C}_{8} \mathrm{H}_{7.33} \mathrm{CuN}_{4.67} \mathrm{O}_{3} \cdot 1.5\left(\mathrm{H}_{2} \mathrm{O}\right): \mathrm{C}, 33.20 ; \mathrm{H}, 2.90 ; \mathrm{N}, 22.59$. Found: $\mathrm{C}, 33.5 ; \mathrm{H}$, 3.1; N, 22.3. UV-vis (nm): 295 vs, 330 vs, sh, 535 s.

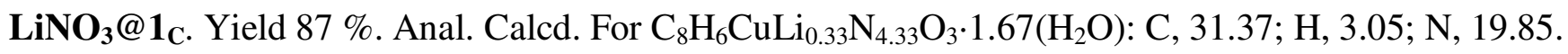
Found: C, 31.4; H, 3.1; N, 19.9. UV-vis (nm): 290 vs, 340 vs, 540 s

$\mathrm{NaNO}_{3} @ 1_{\mathbf{C}}$. Yield $100 \%$. Anal. Calcd. For $\mathrm{C}_{8} \mathrm{H}_{6} \mathrm{CuNa}_{0.33} \mathrm{~N}_{4.33} \mathrm{O}_{3} \cdot 2\left(\mathrm{H}_{2} \mathrm{O}\right)$ : C, 30.21; H, 3.17; N, 19.08 . 
Found: C, 30.1; H, 2.9; N, 19.1.

$\mathbf{K N O}_{3} @ \mathbf{1}_{\mathbf{C}}$. Yield 100 \%. Anal. Calcd. For $\mathrm{C}_{8} \mathrm{H}_{6} \mathrm{CuK}_{0.25} \mathrm{~N}_{4.25} \mathrm{O}_{2.75} \cdot 1.5\left(\mathrm{H}_{2} \mathrm{O}\right): \mathrm{C}, 31.40 ; \mathrm{H}, 2.96 ; \mathrm{N}$, 19.45. Found: C, 31.6; H, 3.1; N, 19.2.

$\mathbf{R b N O}_{3} @ \mathbf{1}_{\mathbf{C}}$. Yield 100 \%. Anal. Calcd. For $\mathrm{C}_{8} \mathrm{H}_{6} \mathrm{CuRb}_{0.25} \mathrm{~N}_{4.25} \mathrm{O}_{2.75} \cdot 1.5\left(\mathrm{H}_{2} \mathrm{O}\right): \mathrm{C}, 30.25 ; \mathrm{H}, 2.86 ; \mathrm{N}$, 18.74. Found: C, 30.5; H, 2.9; N, 18.8.

TINO3 @1 1 . Yield 100 \%. Anal. Calcd. For $\mathrm{C}_{8} \mathrm{H}_{6} \mathrm{CuTl}_{0.29} \mathrm{~N}_{4.29} \mathrm{O}_{2.86} \cdot 1.43\left(\mathrm{H}_{2} \mathrm{O}\right): \mathrm{C}, 27.02 ; \mathrm{H}, 2.51 ; \mathrm{N}$, 16.88. Found: C, 27.2; H, 2.6; N, 16.8.

$\mathbf{L a}\left(\mathbf{N O}_{3}\right)_{3} @ \mathbf{1}_{\mathbf{C}}$. Yield 100 \%. Anal. Calcd. For $\mathrm{C}_{8} \mathrm{H}_{6} \mathrm{CuLa}_{0.25} \mathrm{~N}_{4.75} \mathrm{O}_{4.25} \cdot 1.13\left(\mathrm{H}_{2} \mathrm{O}\right)$ : C, 27.05; H, 2.34; N, 18.73. Found: C, 27.1; H, 2.3; N, 18.3.

Preparation of $\left[\mathrm{Cu}(2-\mathrm{pymo})_{2}\right] \cdot\left(\mathrm{M}\left(\mathrm{NO}_{3}\right)_{\mathrm{m}}\right)_{1 / 2} \cdot(\mathrm{MeOH})_{1 / 2}\left(\mathrm{M}\left(\mathrm{NO}_{3}\right)_{\mathrm{m}} @ 1_{\mathrm{O}}\right), \mathrm{M}=\mathrm{Na}^{+}, \mathrm{K}^{+}, \mathrm{Rb}^{+}, \mathrm{Tl}^{+}$, $\left.\mathbf{B a}^{2+}, \mathbf{L a}^{\mathbf{3 +}}\right)$. These brown microcrystalline solids were obtained by stirring a suspension of $\mathbf{1}_{\mathbf{R}}(150 \mathrm{mg})$ in a $0.05 \mathrm{M}$ solution of the corresponding nitrate salt in $25 \mathrm{~mL}$ of water:methanol (1:4) mixture. The thermodynamic equilibrium is reached at different periods of time ranging from $24 \mathrm{~h}$ for $\mathrm{M}=\mathrm{La}^{3+}$ to 7 days for $\mathrm{M}=\mathrm{Tl}^{+}$and $\mathrm{K}^{+}$. To ensure that the thermodynamic equilibrium was achieved, we have exposed all the samples to the salt solution during 1 week at room temperature. In the case of $\mathrm{M}=\mathrm{Ba}^{2+}$ it should be noted that no previous formation of a cubic phase of type $\left(\mathbf{B a}\left(\mathbf{N O}_{\mathbf{3}}\right)_{\mathbf{2}} @ \mathbf{1}_{\mathbf{C}}\right)$ is observed.

Crystals of $\left(\mathbf{R b N O}_{\mathbf{3}} @ \mathbf{1}_{\mathbf{o}}\right)$ suitable for X-ray analysis were grown from an ammonia:water:methanol (2:11:7) solution $(25 \mathrm{~mL})$ containing $\mathrm{Cu}\left(\mathrm{NO}_{3}\right)_{2} \cdot 3 \mathrm{H}_{2} \mathrm{O}(2 \mathrm{mmol})$, 2-hydroxypyrimidine $\cdot \mathrm{HCl}(4 \mathrm{mmol})$ and $\mathrm{RbNO}_{3}$ (1 mmol). Brown crystals of $\mathbf{R b N O} \mathbf{O}_{\mathbf{3}} @ \mathbf{1}_{\mathbf{o}}$ were obtained after 3 days.

Elemental analyses: 
$\mathrm{NaNO}_{3} @ 1_{0}$ : Yield $100 \%$. Anal. Calcd. for $\mathrm{C}_{8} \mathrm{H}_{6} \mathrm{CuNa}_{0.50} \mathrm{~N}_{4.50} \mathrm{O}_{3.50} \cdot 1\left(\mathrm{CH}_{3} \mathrm{OH}\right) \cdot 1\left(\mathrm{H}_{2} \mathrm{O}\right): \mathrm{C}, 31.78 ; \mathrm{H}$, 2.82; N, 19.62. Found: C, 31.4; H, 2.5; N, 19.6.

$\mathrm{KNO}_{3} @ 1_{\text {o. }}$ Yield $100 \%$. Anal. Calcd. For $\mathrm{C}_{8} \mathrm{H}_{6} \mathrm{CuK}_{0.50} \mathrm{~N}_{4.50} \mathrm{O}_{3.50} \cdot 0.5\left(\mathrm{CH}_{3} \mathrm{OH}\right) \cdot 0.5\left(\mathrm{H}_{2} \mathrm{O}\right): \mathrm{C}, 31.00 ; \mathrm{H}$, 2.75; N, 19.14. Found: C, 31.2; H, 2.8; N, 19.5. UV-vis (nm): 295 vs, 330 vs, sh, 500 s, 640 s, sh.

RbNO3 @1 $\mathbf{1}_{\mathbf{O}}$. Yield 100 \%. Anal. Calcd. For $\mathrm{C}_{8} \mathrm{H}_{6} \mathrm{CuRb}_{0.50} \mathrm{~N}_{4.50} \mathrm{O}_{3.50} \cdot 1\left(\mathrm{CH}_{3} \mathrm{OH}\right) \cdot 1\left(\mathrm{H}_{2} \mathrm{O}\right)$ : C, 28.97; H, 2.57; N, 17.88. Found: C, 29.0; H, 2.6; N, 18.0. UV-vis (nm): 290 vs, 335 vs, sh, 500 s, 640 s, sh.

TINO3@1o. Yield $100 \%$. Anal. Calcd. For $\mathrm{C}_{8} \mathrm{H}_{6} \mathrm{CuTl}_{0.40} \mathrm{~N}_{4.40} \mathrm{O}_{3.20} \cdot 0.4\left(\mathrm{CH}_{3} \mathrm{OH}\right) \cdot 0.4\left(\mathrm{H}_{2} \mathrm{O}\right): \mathrm{C}, 26.53 ; \mathrm{H}$, 2.49; N, 16.21. Found: C, 26.1; H, 3.5; N, 16.5.

$\mathbf{B a}\left(\mathrm{NO}_{3}\right)_{2} @ \mathbf{1}_{\text {o. }}$ Yield $100 \%$. Anal. Calcd. For $\mathrm{C}_{8} \mathrm{H}_{6} \mathrm{CuBa}_{0.50} \mathrm{~N}_{4.50} \mathrm{O}_{3.50} \cdot 0.5\left(\mathrm{CH}_{3} \mathrm{OH}\right) \cdot 0.5\left(\mathrm{H}_{2} \mathrm{O}\right): \mathrm{C}$, 26.98; H, 2.40; N, 16.65. Found: C, 26.5; H, 2.6; N, 16.4.

$\mathbf{L a}\left(\mathbf{N O}_{3}\right)_{3} @ \mathbf{1}_{\mathbf{O}}$. Yield $100 \%$. Anal. Calcd. For $\mathrm{C}_{8} \mathrm{H}_{6} \mathrm{CuLa}_{0.50} \mathrm{~N}_{5.50} \mathrm{O}_{6.50} \cdot 0.25\left(\mathrm{CH}_{3} \mathrm{OH}\right) \cdot 0.25\left(\mathrm{H}_{2} \mathrm{O}\right)$ : C, 23.16; H, 2.04; N, 17.48. Found: C, 23.1; H, 1.8; N, 17.2.

Preparation of orthorhombic $\left[\mathbf{C u}\left(2-\mathbf{p y m o}_{2}\right]_{\mathbf{n}}\left(\mathbf{1}_{\mathrm{O}}\right)\right.$. The microcrystalline empty orthorhombic phase can be obtained by refluxing $150 \mathrm{mg}$ of $\mathbf{K N O}_{\mathbf{3}} @ \mathbf{1}_{\mathbf{o}}$ in $25 \mathrm{~mL}$ in $\mathrm{MeOH}$ in the presence of an excess of 18-crown-6-ether $(150 \mathrm{mg})$ under Ar atmosphere during 6 days. The elemental analysis shows the presence of some $\mathrm{CuO}$ impurity which may be attributed to partial decomposition due to the prolonged heating of the sample. Yield $95 \%$. Anal. Calcd. for $\mathbf{1}_{\mathbf{O}},\left[\mathrm{Cu}\left(\mathrm{C}_{4} \mathrm{H}_{3} \mathrm{~N}_{2} \mathrm{O}\right)_{2}\right] \cdot(\mathrm{CuO})_{0.2} \cdot 2.2 \mathrm{H}_{2} \mathrm{O}: \mathrm{C}, 31.07 ; \mathrm{H}$, 3.39; N, 18.12. Found: C, 31.0; H, 3.1; N, 17.8. UV-vis (nm): 290 vs, 535 s.

Characterisation and physical measurements. Elemental $(\mathrm{C}, \mathrm{H}, \mathrm{N})$ analyses were obtained at a 
FISONS-CARLO ERBA EA 1008 analyser; thermogravimetric analyses were performed on a Schimadzu-TGA-50H equipment in the presence of a dinitrogen atmosphere and electronic spectra on microcrystalline samples were carried out on a Varian Cary UV-vis-NIR spectrophotometer (all these instruments are in Centre of Scientific Instrumentation of the University of Granada). IR spectra were recorded on a ThermoNicolet IR 200 spectrometer by using $\mathrm{KBr}$ pellets.

\section{X-ray Powder Diffraction Characterisation.}

Analytical measurements. Powder X-ray diffractograms of $\mathbf{1}_{\mathrm{R}}, \mathbf{M N O}_{\mathbf{3}} @ \mathbf{1}_{\mathrm{C}}, \mathbf{M}\left(\mathrm{NO}_{3}\right)_{\mathrm{m}} @ \mathbf{1}_{\mathrm{O}}$ and $\mathbf{1}_{\mathrm{o}}$ were performed on a Philips PW1000 using $\mathrm{Cu} K_{\alpha}$ radiation and $\lambda=1.5418 \AA$.

Thermodiffractometry. XRPD data $\left(\mathrm{Cu} K_{\alpha}, \lambda=1.5418 \AA\right)$ were collected on a $\theta: \theta$ Bruker AXS D8 diffractometer equipped with a zero-background $\mathrm{Si}(111)$ monocrystal sample holder located in a remotely-controlled heating stage assembled by Officine Elettrotecniche di Tenno, Italy. Nominal thermal stability: $\pm 0.1{ }^{\circ} \mathrm{C}$.

Ab-initio XRPD structural analysis of $\mathbf{1}_{\mathbf{R}}$. The powders were gently ground in an agate mortar, then cautiously deposited in the hollow of an aluminium holder $0.3 \mathrm{~mm}$ deep. Diffraction data $\left(\mathrm{Cu} K_{\alpha}, \lambda=\right.$ $1.5418 \AA$ A ) were collected on a $\theta: \theta$ Bruker AXS D8 diffractometer equipped with primary and secondary Soller slits $\left(2.3^{\circ}\right)$, divergence, antiscatter and receiving slits $\left(0.5^{\circ}, 0.5^{\circ}\right.$ and $0.2 \mathrm{~mm}$, respectively), secondary beam curved graphite monochromator, $\mathrm{Na}(\mathrm{Tl}) \mathrm{I}$ scintillation detector and pulse height amplifier discrimination. The generator was operated at $40 \mathrm{kV}$ and $40 \mathrm{~mA}$. Nominal resolution for the present set-up is $0.07^{\circ} 2 \theta$ (FWHM of the $\alpha_{1}$ component) as measured from the $\mathrm{Si}(111)$ peak at 
$28.44^{\circ}(2 \theta)$. A long step-scan with $\Delta 2 \theta=0.02^{\circ}$ was performed in the $5<2 \theta<105^{\circ}$ range with $t=30 \mathrm{~s}$.

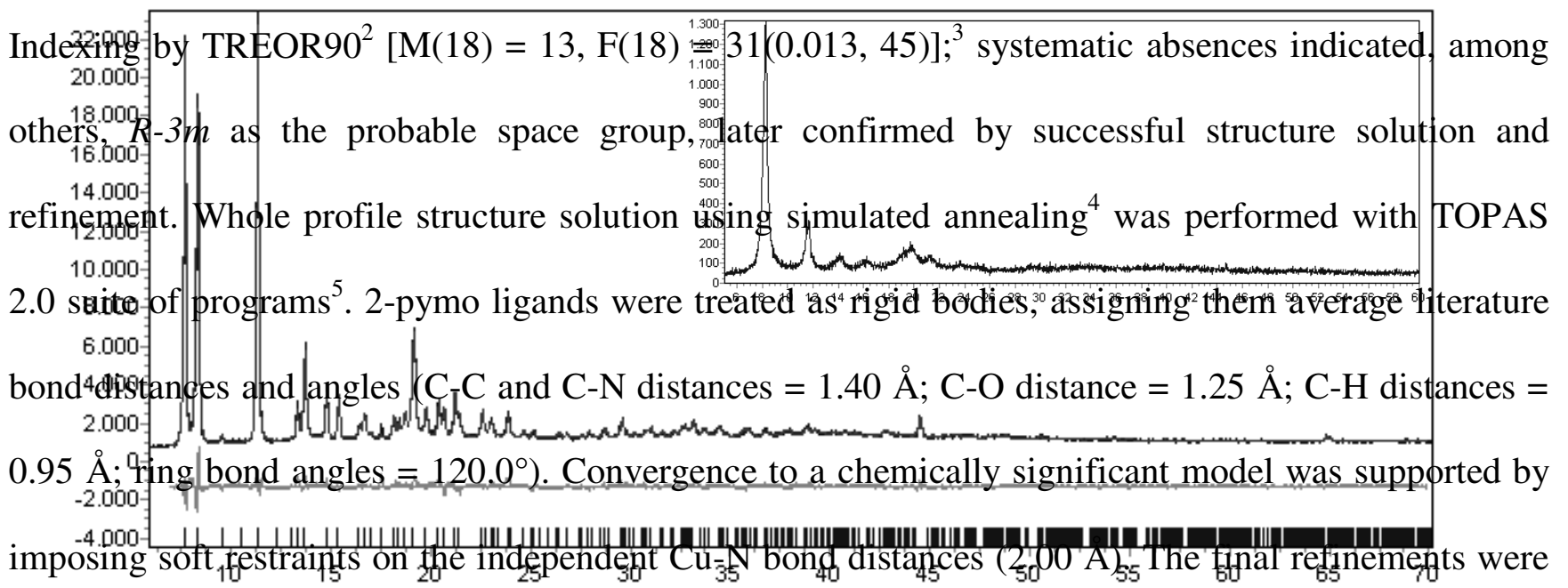

performed by the Rietveld method using TOPAS, maintaining the rigid body and soft restraints described above (statistically significant standard deviations for fractional atomic coordinates are thus not available). Peak shapes were described by the fundamental parameters approach ${ }^{6}$. Experimental background was fit by a polynomial description. Systematic errors were modelled with a sampledisplacement angular shift and a preferred orientation correction in the March-Dollase formulation (with [001] pole ${ }^{7}$ ); copper metal atoms were given a refinable, isotropic displacement parameter $\left(B_{M}\right)$, while lighter atoms were assigned a common $B=B_{M}+2.0 \AA^{2}$ value. Scattering factors, corrected for real and imaginary anomalous dispersion terms, were taken from the internal library of TOPAS.

Crystal data for $\mathbf{1}_{\mathbf{R}} \mathrm{C}_{8} \mathrm{H}_{8} \mathrm{CuN}_{4} \mathrm{O}_{3}$, fw $271.72 \mathrm{~g} \mathrm{~mol}^{-1}$, trigonal, $R-3 m$, a $=23.040(2), \mathrm{c}=25.140(2) \AA, \mathrm{V}$ $=11.558(2) \AA^{3}, Z=36 ; \rho=1.405 \mathrm{~g} \mathrm{~cm}^{-3} ; R_{w p}, R_{p}$ and $R_{\text {Bragg }} 0.057,0.043$ and 0.022 , for 3150 data collected in the $7-70^{\circ} 2 \theta$ range.

\footnotetext{
${ }^{2}$ Werner, P. E.; Eriksson, L.; Westdahl, M. J. Appl. Crystallogr. 1985, 18, 367.

3 a) De Wolff, P. M. J. Appl. Crystallogr. 1968, 1, 108. b) Smith, G. S.; Snyder, R. L. J. Appl. Crystallogr. 1979, $12,60$.

${ }^{4}$ Coelho, A. A. J. Appl. Crystallogr. 2000, 33, 899.

${ }^{5}$ Bruker AXS 2000: Topas V2.0: General profile and structure analysis software for powder diffraction data.

${ }^{6}$ Cheary, R. W.; Coelho, A. A. J. Appl. Crystallogr. 1992, 25, 109.

7 a) March, A. Z. Kristallogr.,1932, 81, 285. b) Dollase, W. A. J. Appl. Crystallogr. 1987, $19,267$.
} 
Figure S.1. Rietveld refinement plot for the XRPD analysis of pristine (hydrated) $\left[\mathrm{Cu}(2-\text { pymo })_{2}\right]_{\mathrm{n}}, \mathbf{1}_{\mathrm{R}}$; the insert shows the XRPD trace of the evacuated $\mathbf{1}_{\mathrm{C}}$ cubic phase obtained upon gentle heating.

Single crystal X-ray Analysis. Single crystal X-ray intensity data for $\mathbf{N H}_{4} \mathbf{N O}_{3} @ \mathbf{1}_{\mathrm{C}}, \mathbf{L i N O}_{3} @ \mathbf{1}_{\mathrm{C}}$ and $\mathbf{R b N O}_{3} @ 1_{O}$ were collected with a BRUKER SMART APEX $\left(\mathrm{Mo}_{\mathrm{K}_{\alpha}}, \lambda=0.71069 \AA\right.$, graphite monochromator) (Centre of Scientific Instrumentation of the University of Granada). In all cases, the whole sphere reciprocal space was covered by measurements of 360 frames. Preliminary orientation matrices and unit cell parameters were obtained from the peaks of the first 10 frames and were refined using the whole data set. Frames were integrated and corrected for Lorentz and polarization effects using DENZO. ${ }^{8}$ The scaling and the global refinement of crystal parameters were performed by SCALEPACK. ${ }^{8}$ Reflections that were partly measured on previous and following frames were used to mutually scale these frames. The crystals were corrected from absorption by multiscan method.

Structure solution and refinements. The single crystal structures were solved by standard direct methods ${ }^{9}$ and refined by full-matrix least squares methods based on $F^{2}$ using the SHELXTL-PLUS ${ }^{10}$ and SHELXL-97 programs. ${ }^{11}$ The atom scattering factors were taken as those given in the SHELXTLPLUS program. Transmission factors were calculated using SHEXL-97. ${ }^{11}$ For $\mathbf{R b N O}_{\mathbf{3}} @ \mathbf{1}_{\mathbf{0}}$ all nonhydrogen atoms were refined anisotropically. In the case of $\mathbf{L i N O}_{3} @ \mathbf{1}_{\mathrm{C}}$ and $\mathbf{N H}_{4} \mathbf{N O}_{3} @ \mathbf{1}_{\mathrm{C}}$ crystal

\footnotetext{
${ }^{8}$ Otwinowsky, Z.; Minor, W. "Processing of X-ray Diffraction Data Collected in Oscillation Mode", Methods in Enzymology (Eds.: C. W. Carter, Jr., R. M. Sweet), Academic Press, 1996, p. 276.

${ }^{9}$ Sheldrick, G. M. Acta Crystallogr. 1990, A46, 467-473.

${ }^{10}$ Sheldrick, G. M. SHELXTL-PLUS (VMS). Siemens Analytical X-ray Instruments, Inc. Madison WI, 1990.

${ }^{11}$ Sheldrick, G. M. SHELXL-97, Program for the refinement of Crystal structures, University of Göttingen (Germany), 1997.
} 
structures, the $\left[\mathrm{Cu}(2-\text { pymo })_{2}\right]_{\mathrm{n}}$ frameworks are well defined while the $\left[\mathrm{Li}\left(\mathrm{H}_{2} \mathrm{O}\right)_{4}\right] \mathrm{NO}_{3}$ and $\mathrm{NH}_{4} \mathrm{NO}_{3} \cdot 2 \mathrm{H}_{2} \mathrm{O}$ guests appear disordered as a result of the high symmetry of the recognition sites. In the crystal structure of $\mathbf{L i N O}_{\mathbf{3}} @ \mathbf{1}_{\mathbf{C}}$, the two nitrates and two $\left[\mathrm{Li}\left(\mathrm{H}_{2} \mathrm{O}\right)_{4}\right]^{+}$groups included in the sodalite type $\beta$-cages are distributed in four equivalent positions. This results in a close contact between the $\mathrm{O} 1 \mathrm{~N}$ atom of the nitrate group and the water molecule $\mathrm{O} 2 \mathrm{w}$ coordinated to the lithium atom. Therefore, the nitrate group has been treated as a rigid body and the $\mathrm{Li}-\mathrm{O} 2 \mathrm{w}$ distance was constrained. Likewise, in $\mathbf{N H}_{\mathbf{4}} \mathbf{N O}_{\mathbf{3}} @ \mathbf{1}_{\mathbf{C}}$, the two nitrate groups are distributed in four equivalent positions while the water molecules and ammonium ions are found to be distributed respectively in 12 and 6 equivalent positions near a $-3 m$ symmetry site.

Crystallographic data (excluding structure factors) for the structures reported in this paper have been deposited with the Cambridge Crystallographic Data Centre supplementary publication no. CCDC223567-223570. Copies of the data can be obtained free of charge on application to CCDC, 12 Union Road, Cambridge CB21EZ, UK (Fax: (+44)1223-336-033; E-mail: deposit@ ccdc.cam.ac.uk). 
Table S.1. Crystallographic data of compounds $\mathbf{N H}_{\mathbf{4}} \mathbf{N O}_{\mathbf{3}} @ \mathbf{1}_{\mathbf{C}}, \mathbf{L i N O} \mathbf{H}_{\mathbf{3}} @ \mathbf{1}_{\mathbf{C}}$ and $\mathbf{R b N O} \mathbf{O}_{3} @ \mathbf{1}_{\mathbf{O}}$.

\begin{tabular}{|c|c|c|c|}
\hline Compound & $\mathbf{N H}_{4} \mathbf{N O}_{3} @ \mathbf{1}_{\mathrm{C}}$ & LiNO $_{3} @ \mathbf{1}_{\mathbf{C}}$ & $\mathbf{R b N O}_{3} @ 1_{0}$ \\
\hline Empirical formula & $\begin{array}{l}\mathrm{Cu}(2 \text {-pymo })_{2} \cdot \\
\left(\mathrm{NH}_{4} \mathrm{NO}_{3} \cdot 2 \mathrm{H}_{2} \mathrm{O}\right)_{1 / 3}\end{array}$ & $\begin{array}{l}\mathrm{Cu}(2-\mathrm{pymo})_{2} \cdot \\
\left(\mathrm{Li}\left(\mathrm{H}_{2} \mathrm{O}\right)_{4} \mathrm{NO}_{3}\right)_{1 / 3}\end{array}$ & $\begin{array}{l}\mathrm{Cu}(2-\mathrm{pymo})_{2} \\
\left(\mathrm{Rb}\left(\mathrm{H}_{2} \mathrm{O}\right) \mathrm{NO}_{3}\right)_{1 / 2}\end{array}$ \\
\hline FW & 296.4 & 298.4 & 361.5 \\
\hline Crystal system & Cubic & Cubic & Orthorhombic \\
\hline Space group & Pn-3m & Pn-3m & Pna $2_{1}$ \\
\hline$a[\AA]$ & $15.67(5)$ & $15.65(5)$ & $18.78(2)$ \\
\hline$b[\AA]$ & $15.67(5)$ & $15.65(5)$ & $11.02(1)$ \\
\hline$c[\AA]$ & $15.67(4)$ & $15.65(5)$ & $11.45(1)$ \\
\hline$\alpha\left[^{\circ}\right]$ & 90 & 90 & 90 \\
\hline$\beta\left[^{\circ}\right]$ & 90 & 90 & 90 \\
\hline$\gamma\left[^{\circ}\right]$ & 90 & 90 & 90 \\
\hline$V\left[\AA^{3}\right]$ & $3847.9(2)$ & $3831.2(2)$ & $2370.0(2)$ \\
\hline $\mathrm{Z}(\mathrm{Cu})$ & 12 & 12 & 8 \\
\hline$V / Z$ & 320.67 & 319.25 & 296.25 \\
\hline $\mathrm{Cu} . . . \mathrm{Cu}\left[\AA^{3}\right]$ & 5.54 & 5.53 & 5.47 \\
\hline$\rho_{\text {calcd }}\left[\mathrm{Mg} / \mathrm{m}^{-3}\right]$ & 1.55 & 1.60 & 2.03 \\
\hline$\mu\left(\mathrm{Mo}-\mathrm{K}_{\alpha}\right)\left[\mathrm{mm}^{-1}\right]$ & 1.72 & 1.73 & 3.91 \\
\hline$T(\mathrm{~K})$ & $298(2)$ & $298(2)$ & $298(2)$ \\
\hline Crystal size $[\mathrm{mm}]$ & $0.10 \times 0.10 \times 0.10$ & $0.15 \times 0.15 \times 0.15$ & $0.20 \times 0.15 \times 0.10$ \\
\hline $2 \theta_{\max }\left[^{[}\right]$ & 58 & 57 & 56 \\
\hline Reflns. Collected & 5314 & 23395 & 12542 \\
\hline Independent rflns. & 865 & 925 & 4776 \\
\hline Reflns. Obs & 256 & 738 & 3840 \\
\hline Parameters refined & 58 & 57 & 343 \\
\hline$R_{l}^{[\mathrm{a}]}$ & 0.081 & 0.063 & 0.063 \\
\hline$W R_{2}{ }^{[\mathrm{b}]}$ & 0.23 & 0.18 & 0.178 \\
\hline Goodness of fit & 0.967 & 1.117 & 1.077 \\
\hline Residuals $\left[\mathrm{e}^{-3}\right]$ & $0.063 /-0.005$ & $1.133 /-0.177$ & $3.306 /-1.881$ \\
\hline
\end{tabular}


Figure S.2. Packing diagram for (hydrated) $\mathbf{1}_{\mathbf{R}}$. Hydrogen atoms are omitted for clarity. $\mathrm{Cu}$ (pale red), $\mathrm{N}$ (blue), C (black), water molecules (yellow).

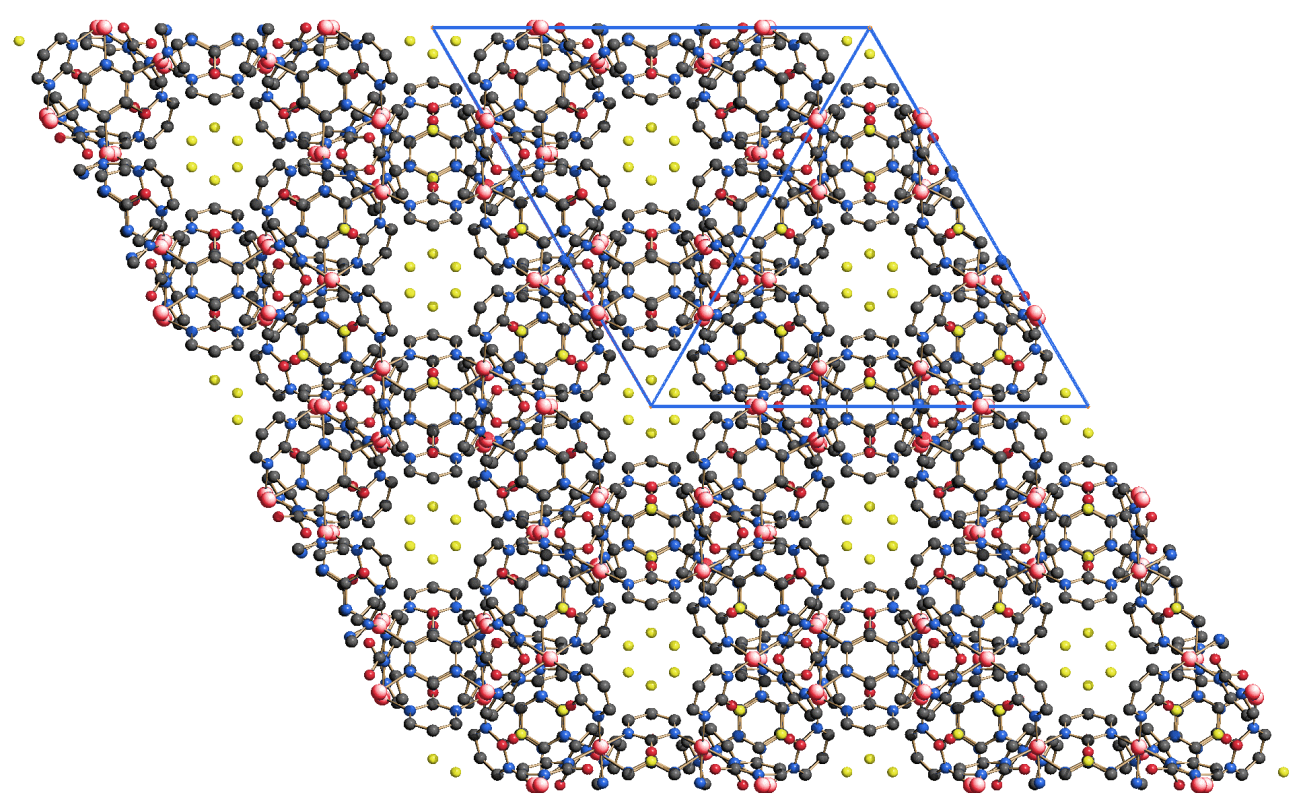

Figure S.3. View of the supramolecular recognition pattern of the $\left[\mathrm{NH}_{4}\left(\mathrm{H}_{2} \mathrm{O}\right)_{2}\right] \mathrm{NO}_{3}$ ion pair in the crystal structure of $\mathbf{N H}_{4} \mathbf{N O}_{3} @ \mathbf{1}_{\mathbf{C}} . \mathrm{Cu}$ (green), N (blue), O (red), C (grey).

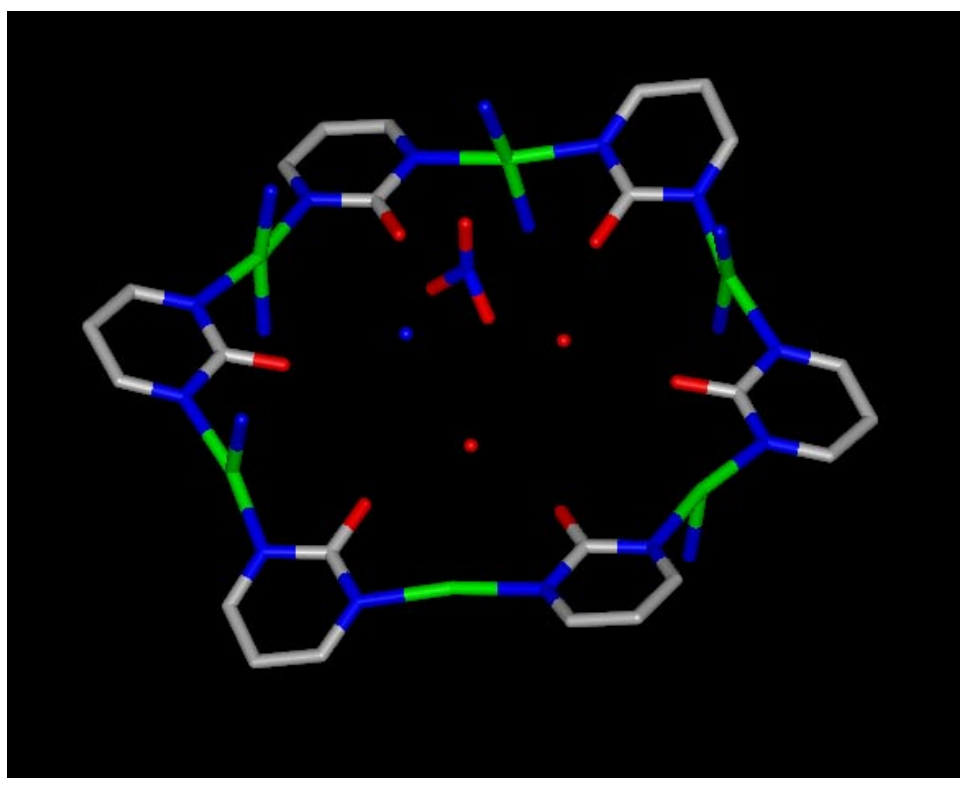


Figure S.4. View of the $\left[\mathrm{Cu}(2-\text { pymo })_{2}\right]_{n}$ framework in the crystal structures of isomorphous $\mathbf{M N O}_{\mathbf{3}} @ \mathbf{1}_{\mathbf{C}}$ systems. For sake of clarity, guest ions and molecules are omitted. Cu (green), N (blue), O (red), C (grey).

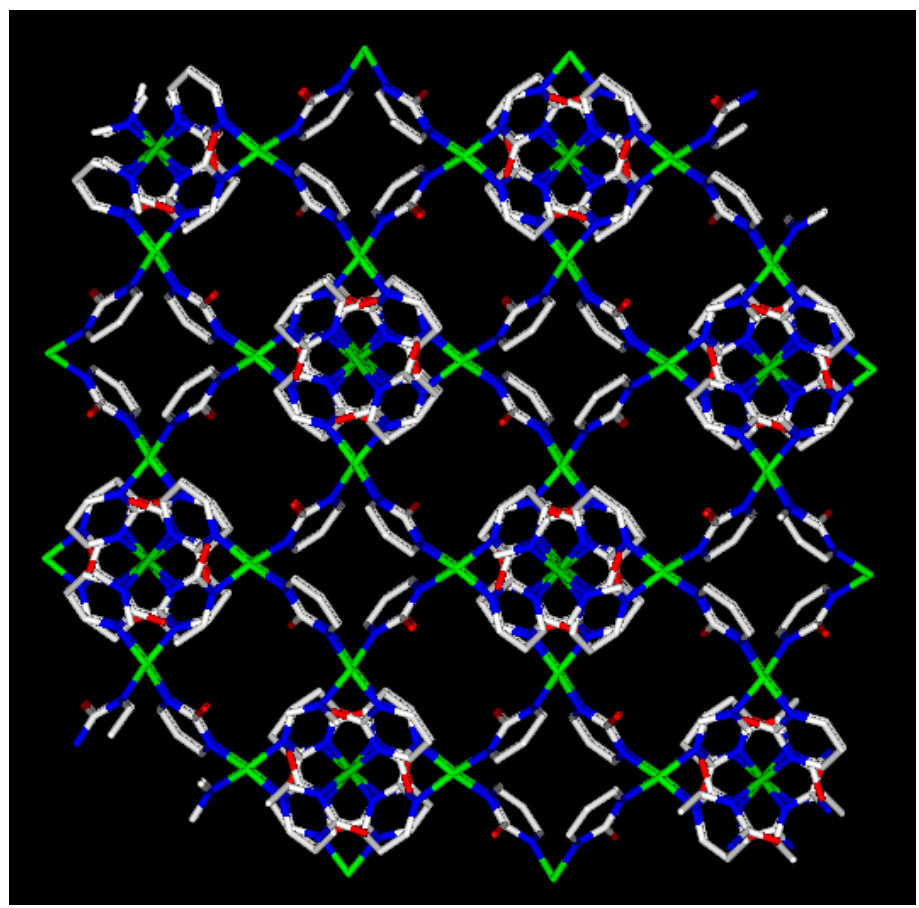

Figure S.5. Packing diagram of $\mathbf{R b N O}_{3} @ \mathbf{1}_{\mathbf{0}}$. Cu (green), N (blue), O (red), C (grey), Rb (purple).

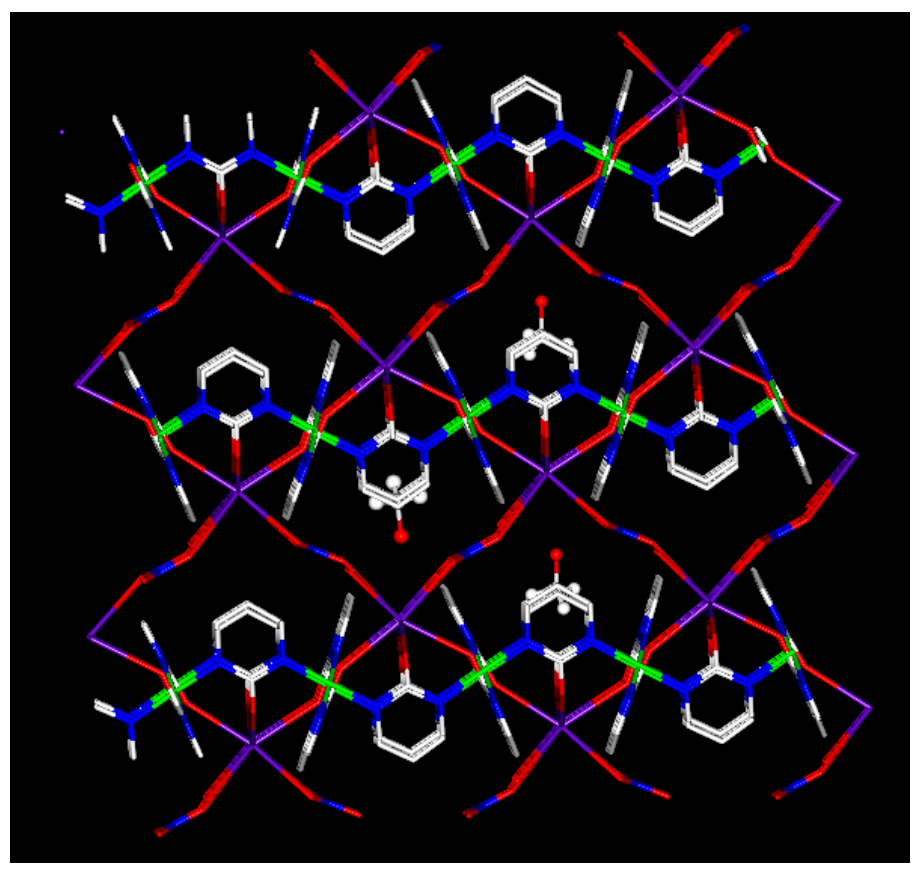


Figure S.6. Schematic interconversion processes sensitive to ion pair recognition taking place in the $\left[\mathrm{Cu}(2-\text { pymo })_{2}\right]_{\mathrm{n}}$ framework upon exposition to $\mathrm{KNO}_{3}$. IR spectra (left) and XRPD (right) of the different steps in the sequential sorption process.

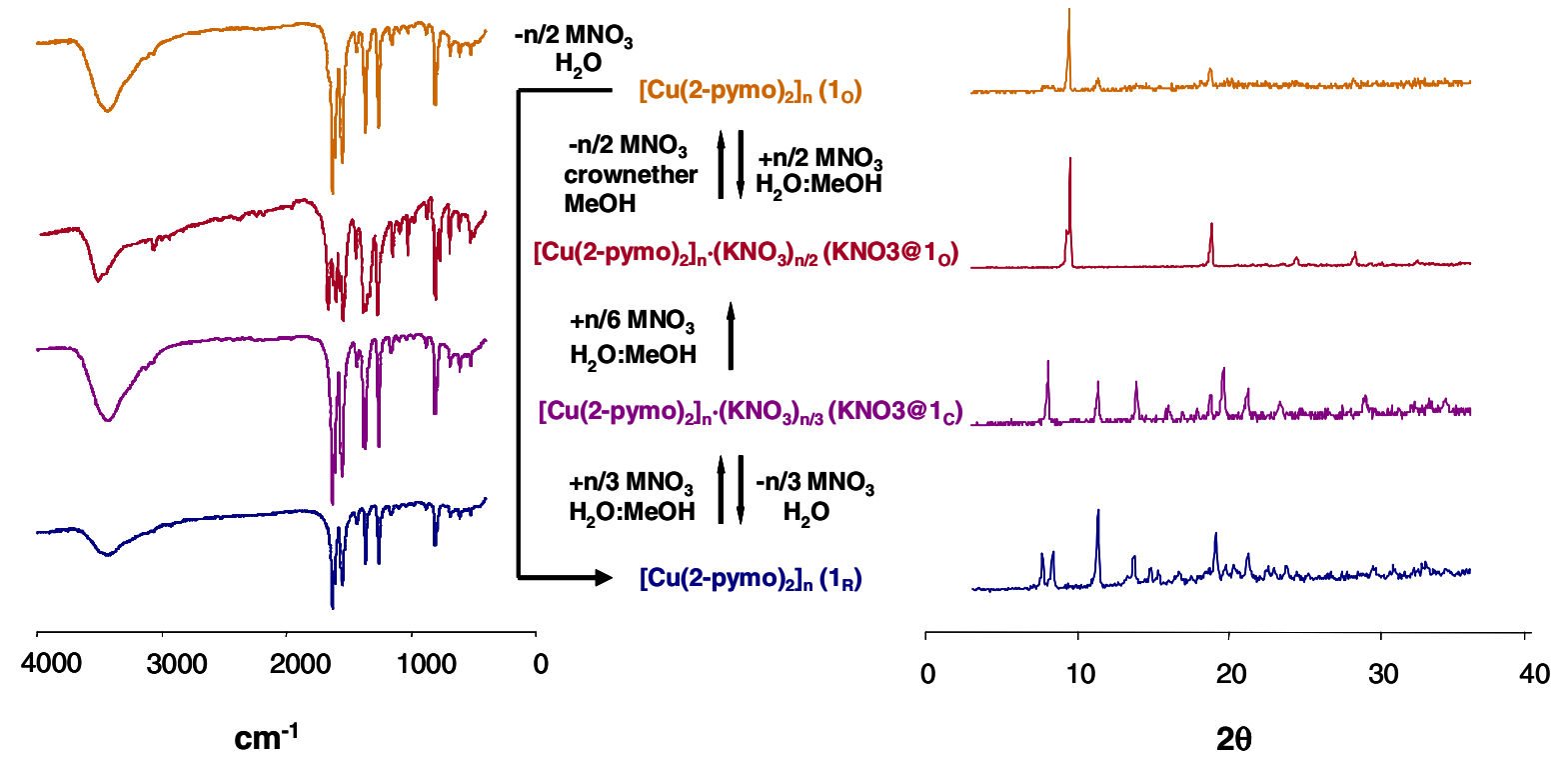


Figure S.7. XRPD diagrams of the layered $\left[\mathrm{Cu}(2-\mathrm{pymo})_{2}\right]_{\mathrm{n}} \cdot\left(\mathrm{M}\left(\mathrm{NO}_{3}\right)_{\mathrm{m}}\right)_{\mathrm{n} / 2}\left(\mathbf{M}\left(\mathbf{N O}_{3}\right)_{\mathbf{m}} @ \mathbf{1}_{\mathbf{o}}\right)$. The 200 reflection was used to estimate the effect of $\mathrm{M}\left(\mathrm{NO}_{3}\right)_{\mathrm{m}}$ guest incorporation on the a parameter.

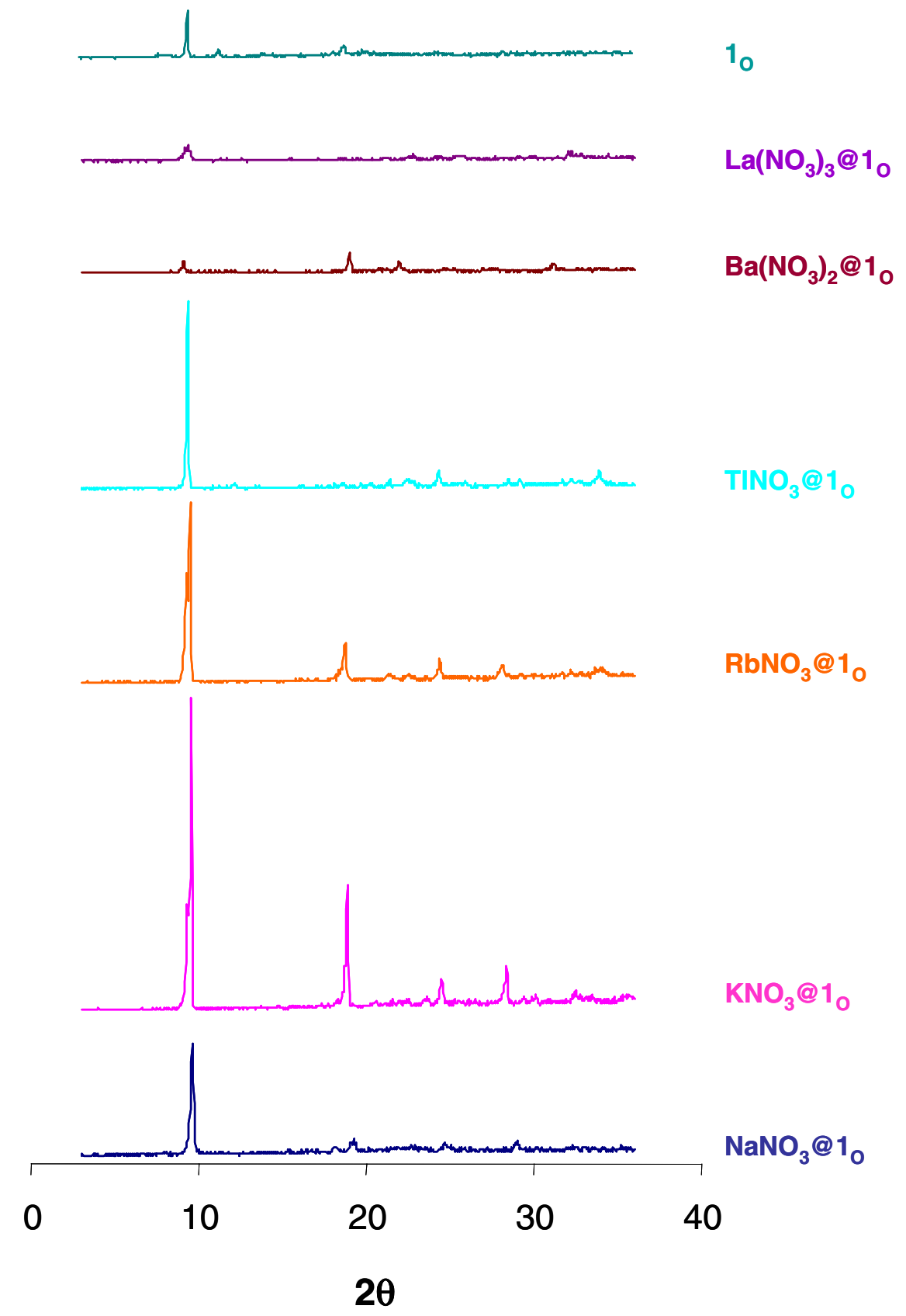

